\title{
Determinants of the Adoption Academic Electronic Books by University Students in a Developing Country
}

Foluke Okocha, Landmark University, Nigeria

\begin{abstract}
Higher education institutions worldwide are transitioning to electronic books which have become a standard platform in providing reading materials. This study investigated the determinants of the adoption of academic e-books by university students in Nigeria. Results showed that a majority of students were aware of electronic books but only $44.5 \%$ of students used them often. Despite the availability of these resources, more than $50 \%$ of students did not use e-books, also surprising was that majority of students discovered e-books from their lecturers. The study further revealed that performance expectancy, effort expectancy, and facilitating conditions were major determinants in the adoption of e-books by undergraduate students. However, social influence and gender did play a significant role in the intention to adopt electronic books by undergraduate students. This study has practical implications on academic institutions and electronic book publishers in encouraging e-book use and improving e-book features to align with the needs of the millennial students and also providing reliable internet facilities and improving lecturer and institutional support in driving e-book adoption by undergraduate students.
\end{abstract}

\section{KEYWORDS}

Adoption, Electronic Books, Nigeria, University Students

\section{INTRODUCTION}

\subsection{Research Background}

The emergence of Electronic Books (e-books) has caused a change in the access of information; information now transcends beyond boundaries and is available and accessible at any time. Higher education institutions worldwide are transitioning to e-books, which have become a standard platform in providing reading materials (Aharony, 2014). Majority of undergraduate students are considered as digital natives who show familiarity with and have great potential to adopt electronic books. However, academic libraries are advised to change how these services are offered to undergraduate students (Ashcroft, 2011).

E-books are digital versions of traditional print books that are readable across a variety of computing platforms including personal computers, tablets, smartphones and purpose-designed

\section{DOI: 10.4018/IJICTE.2020100108}

This article, originally published under IGI Global's copyright on October 1, 2020 will proceed with publication as an Open Access article starting on January 25, 2021 in the gold Open Access journal, International Journal of Information and Communication Technology Education (converted to gold Open Access January 1, 2021), and will be distributed under the terms of the Creative Commons Attribution License (http://creativecommons.org/licenses/by/4.0/) which permits unrestricted use, distribution, and production in any medium, provided the author of the original work and original publication source are properly credited. 
agents, known as e-book readers (Reitz, 2014). Also, the proliferation of mobile technologies and e-book readers has led to increased access of e-books. Renner predicts that e-books, like e-journals, will be the norm in academia by the year 2020. The benefits of e-books are enormous ranging from its portability, storage size, cost, ease of access, convenience, hyperlink features amongst others.

However, despite the enormous benefits allotted to e-books, students still consider e-books difficult to use and do not find e-book features beneficial or engaging (Huang et al., 2012). The inclusion of e-textbook features, such as increased mobility and accessibility, has not changed students' resistance to this technology. (Gu, Wu, \& Xu, 2015; Van Horne, Russell, \& Schuh, 2015). Many students still resist e-books and will only switch to e-books when rewards are attached (Abutaleb, 2012). Terpend et al. (2014) in examining the factors that influence students' adoption of e-books attributed ease of use and price of e-books as the major factors influencing the adoption of e-books. However, these findings differed from Gerhart et al. (2015) who stated the adoption of e-books is low due to functional differences from the traditional model. This study seeks to understand the variables that influence the adoption of electronic books.

\subsection{Problem Statement}

The dearth of current literature in academic libraries in Nigeria has brought about the need for the adoption of e-book in Nigerian Universities (Nwagwu, 2015). However, the acceptance of e-books in Africa is still at its infancy. Maepa and Nkosi (2013) identified factors that have limited the acceptance to include high e-book prices, scarcity of e-books produced in Africa, Internet challenges and lack of framework for digital publishing. The adoption of e-books is slow in spite of the fact that the internet and other mobile technologies which enable e-book use are gaining popularity. The adoption of smartphones in Nigeria is projected to increase to 23.3 million by 2019, yet the projected growth rate in the e-book industry is not yet realized (Shinn, 2011. Brown (2013) argues that e-books are continuously gaining popularity, but successful e-book adoption and user acceptance is not universal as review of prior research studies shows mixed results. Hence, this study focuses on the factors that lead to the adoption of e-books by university students in Nigeria which is the gap this study seeks to clear.

The acceptance of a technology is the major driving factor for its adoption and diffusion in a given society. Several models have been used by researchers to investigate technology acceptance. This study adopts a combination of the UTAUT model, and Innovation Resistance model to propose a framework for the adoption and invariably acceptance of e-books in Nigeria. Unified theory of acceptance and use of technology (UTAUT) propounded by Venkatesh (2003) integrated eight models in explaining the behavioural intention and the actual usage of an information system. The UTAUT model is capable of explaining as high as $70 \%$ the use of an information system. It has been proven to be better than previous models. It postulates that four constructs are determinants to the behavioural intention and the actual usage of an information system. They include performance expectancy, effort expectancy, social influence and facilitating conditions. The effect is moderated by age, gender and experience.

\subsection{Objective of Study}

The overall objective of this study is determining the factors that lead to the acceptance of e-books by university students in Nigeria. The specific objectives include:

- Identify the awareness of rate against the usage ratio of e-books in Nigeria;

- Establish factors that influence acceptance of e-books by students;

- Establish the relationship between gender and the acceptance of e-books. 


\section{REVIEW OF LITERATURE}

Several studies on the adoption of electronic books by undergraduate students have been conducted globally (Verkijika, 2019; Wang \& Bai, 2016; Liu \& Huang, 2016; Raynard, 2017, Nwagwu, 2015 Aharony, 2014). Several factors have been identified to influence the adoption of electronic books, and these include awareness (Wang \& Bai, 2016), perceived usefulness (Joo \& Choi, 2015; Shin, 2011), perceived ease of use (Joo \& Choi, 2015), techno stress (Verkijika, 2019) and attitude (Wang $\&$ Bai, 2016) amongst others. These studies reveal that the adoption of electronic books is a major challenge globally and researchers are seeking to understand reasons influencing its low adoption among millennial students. Potnis, Deosthali, Zhu, and McCustker (2018) examined factors that influenced undergraduate students use of electronic books in the United States using a mixed method study, results revealed that ease of access of electronic books do not eventually lead to use by undergraduate students. The study further showed that environment for information technology use, perceived enjoyment, electronic book features, locus of control and subjective norm influenced the adoption of electronic books in the United States. Similarly, Wang and Bai (2016) conducted a study of university students' awareness, usage and attitude towards electronic books in China. The study revealed that undergraduate students majorly access electronic books on search engines as awareness and usage of library provided e-books were relatively low. The study further showed that undergraduate students used e-books majorly for leisure and showed preference for printed books for academic purposes. Liu and Huang (2016) investigated the reading behavior of undergraduate smart phone users in China; the study showed that reading e-books on smart phone involved more scanning and less in depth reading with minimal concentration. Verkijika (2019) showed the role of techno stress in the adoption of electronic books, results revealed that techno stress played a negative influence on the adoption of digital textbooks. A study by Raynard (2017) has also revealed that the role of marketing and educational strategies in improving the adoption of electronic books globally.

\subsection{Theoretical Background and Hypothesis}

User acceptance is critical to determine the success or failure of an information system (Davis, 1993). Unified theory of acceptance and use of technology (UTAUT) propounded by Venkatesh (2003) integrated eight models in explaining the behavioural intention and the actual usage of an information system.

The UTAUT model is capable of explaining as high as $70 \%$ the use of an information system. It has been proven to be better than previous models It postulates that four constructs are determinants to the behavioural intention and the actual usage of an information system. They include performance expectancy, effort expectancy, social influence and facilitating conditions. The effect is moderated by age, gender, and experience.

Performance expectancy is the degree a student believes using an e-book will improve academic performance. This has been tested and is the strongest predictor of behavioural intention (Venkatesh et al., 2003). Effort expectancy (EE) refers to the degree of ease associated with reading e-books. Social influence (SI) is the extent to which believes that important others believe e-books should be used. For the purpose of this study this includes lecturers, colleagues, and friends. Finally, facilitating conditions (FC) is the degree a student believes organizational and technical structures support the use of e-books. The Proposed hypothesis for this study is:

H1: Performance expectancy will significantly affect students' behavioural intention to read e-books.

H2: Effort expectancy will significantly affect students' behavioural intention to read e-books.

H3: Social influence will significantly affect students' behavioural intention to read e- books.

H4: Facilitating conditions will significantly affect student's intention to read e-books. 
The roles of age and gender in the acceptance of technologies have been argued by researchers (Venkatesh et al. 2003; Wang \& Wang 2010). Performance expectancy is said to be stronger in men (Venkatesh \& Morris, 2000) while Effort Expectancy and Social Influence have move effect in women (Venkatesh \& Morris, 2000). Hence:

H5: Gender has moderating effect on performance expectancy, effort expectancy and social influence.

Figure 1. UTAUT model

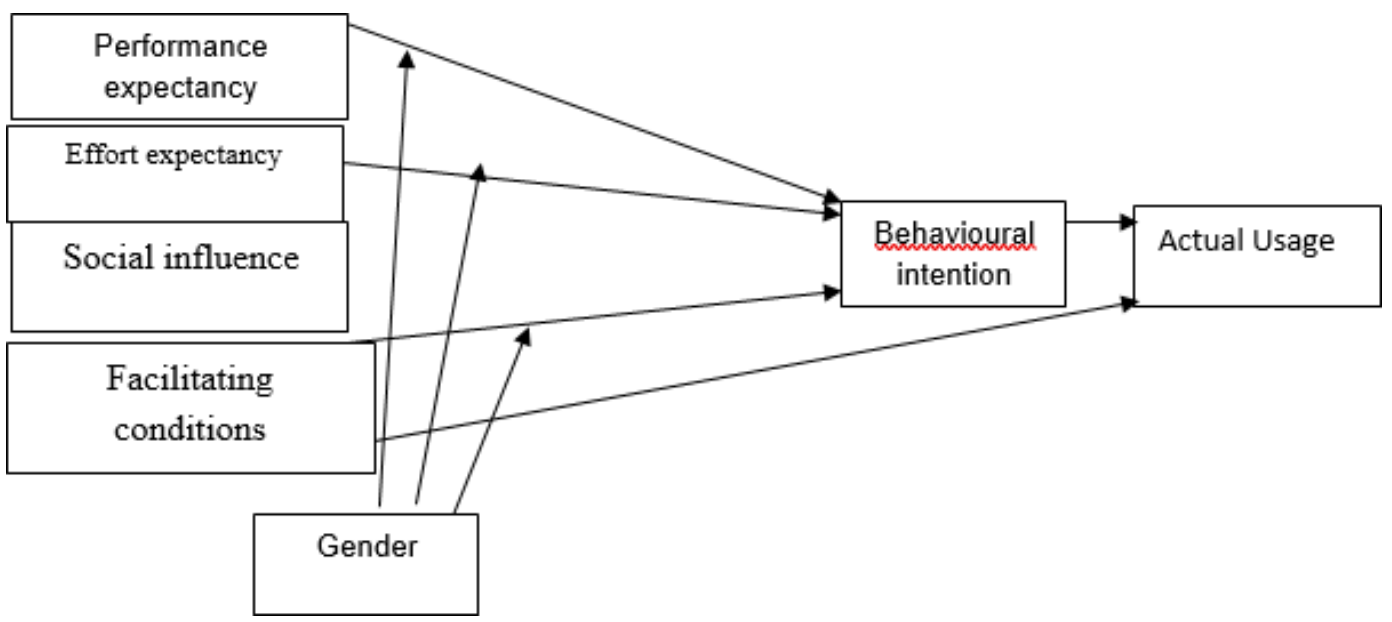

\section{METHODOLOGY}

\subsection{Data Collection}

The study examined the determinants of the adoption of electronic books by undergraduate students in Landmark University. Students were categorized based on College of Study and this included College of Business and Social Science, College of Agricultural Science and College of Science and Engineering. A total of three hundred questionnaires were distributed of which 287 were returned, the questionnaires were further designed based on constructs from the UTAUT model and further designed using the 7-point Linkert scale. The questionnaire consisted majorly on close ended questions. The design was guided by the UTAUT model.

\subsection{Measures}

The questionnaire is designed using the UTAUT model. The study includes four dependent variable (performance expectancy, effort expectancy, social influence \& facilitating conditions) and one independent variable (behavioral intention). Table 1 shows constructs and variables adopted from the UTAUT model.

\subsection{Reliability of Constructs}

\subsubsection{Validity and Reliability}

The results in Table 2 showed that item loadings were greater than 0.5. All constructs were tested for reliability and it was noted that all constructs were valid having a Cronbach alpha greater than 0.7. 
Table 1. Constructs adopted from UTAUT model

\begin{tabular}{|l|l|}
\hline \multicolumn{1}{|c|}{ Constructs } & \multicolumn{1}{c|}{ Variables } \\
\hline $\begin{array}{l}\text { Performance } \\
\text { Expectancy }\end{array}$ & $\begin{array}{l}\text { Using E-books improves my performance in courses I take } \\
\text { E-books are important for my academic success } \\
\text { E-books stimulate my interest in my course } \\
\text { E-books enable me access books at convenience }\end{array}$ \\
\hline $\begin{array}{l}\text { Effort } \\
\text { expectancy }\end{array}$ & $\begin{array}{l}\text { E-books are easy to search from home } \\
\text { I like reading books from the computer screen } \\
\text { E-books are easy to locate } \\
\text { I like using e-books because I don't have to borrow }\end{array}$ \\
\hline Social Influence & $\begin{array}{l}\text { Most of my classmates use e-books to support lecture materials } \\
\text { My lecturers think it is a good idea to use E-books } \\
\text { My class representatives use E-books. }\end{array}$ \\
\hline $\begin{array}{l}\text { Facilitating } \\
\text { Conditions }\end{array}$ & $\begin{array}{l}\text { I have sufficient bandwidth to read E-books } \\
\text { I have adequate knowledge necessary to use E-books } \\
\text { Internet facilities are fast enough to read E-books } \\
\text { My lecturers use e-books to support teaching }\end{array}$ \\
\hline $\begin{array}{l}\text { Behavioral } \\
\text { Intention }\end{array}$ & $\begin{array}{l}\text { I prefer using e-books than to visit the library } \\
\text { E-books is a good idea because I don't need to borrow } \\
\text { I will like to have a folder of e-books related to my courses } \\
\text { Using e-books will improve my performance in courses I take }\end{array}$ \\
\hline
\end{tabular}

Table 2. Cronbach Alpha reliability test

\begin{tabular}{|l|l|}
\hline \multicolumn{1}{|c|}{ Constructs } & \multicolumn{1}{c|}{ Cronbach Alpha (Reliability Test) } \\
\hline Performance Expectancy & 0.729 \\
\hline Effort Expectancy & 0.717 \\
\hline Social Influence & 0.734 \\
\hline Facilitating Condition & 0.710 \\
\hline Intention to adopt e-books & 0.740 \\
\hline
\end{tabular}

\section{RESULT}

\subsection{Demographics}

In analysis of the demographic profile of respondents, the majority was male with $68.1 \%$, the respondents were evenly distributed among all levels of study. A higher percentage $(58.3 \%)$ of respondents' were from college of science and engineering, while the least were from college of agricultural sciences (3.5\%) (see Table 3).

\subsection{Awareness and Usage of e-Books}

Figure 2 and 3 shows the number of respondents who were aware of e-books; A high percentage (97.9\%) of respondents were aware of eBooks. A significant proportion (46.6\%) specified they had used e-books once while $44.5 \%$ stated that they used e-books often. Only $8.5 \%$ of respondents reported never to have used e-books. 
Table 3. Gender, level of study and college of respondents

\begin{tabular}{|l|l|l|}
\hline & Frequency & Percentage \\
\hline Gender & & \\
\hline Male & 175 & 61.8 \\
\hline Female & 108 & 38.2 \\
\hline Level of Study & & \\
\hline 100 Level & 30 & 10.6 \\
\hline 200 Level & 83 & 29.3 \\
\hline 300 Level & 62 & 21.9 \\
\hline 400 Level & 79 & 27.9 \\
\hline 500 Level & 29 & 10.2 \\
\hline College of Study & & \\
\hline College of Agricultural Sciences & 10 & 3.5 \\
\hline College of Business and Social Sciences & 108 & 38.2 \\
\hline College of Science and Engineering & 165 & 58.3 \\
\hline
\end{tabular}

Figure 2. Awareness and use of e-books

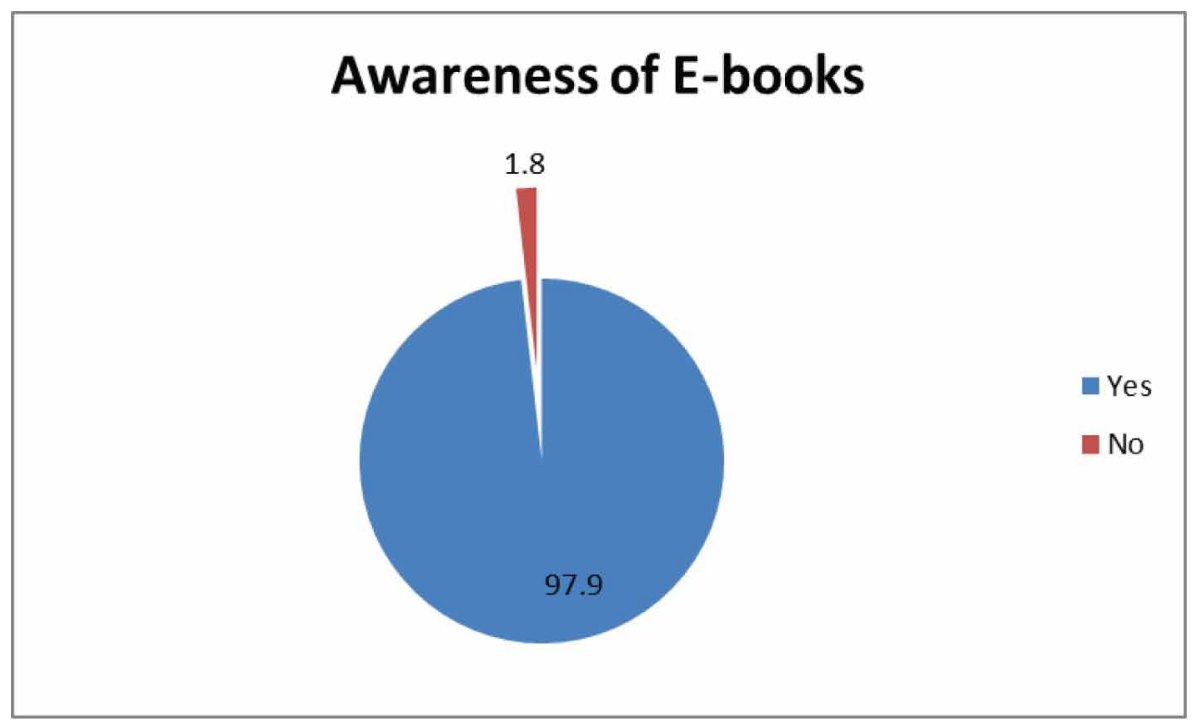

\subsection{Awareness and Familiarity With e-Book Services Provided by the University}

Table 4 shows $94.7 \%$ of respondents were aware the university provides access to e-book services. However, only $49.1 \%$ of the respondents were familiar with ebrary which amounted to the e-book service majorly used by the respondents, $34.3 \%$ of respondents made use of science direct e-books and only $7.8 \%$ of respondents made use of EBSCO e-books. Other e-books used by students were Teal and Oare eBook collections. 


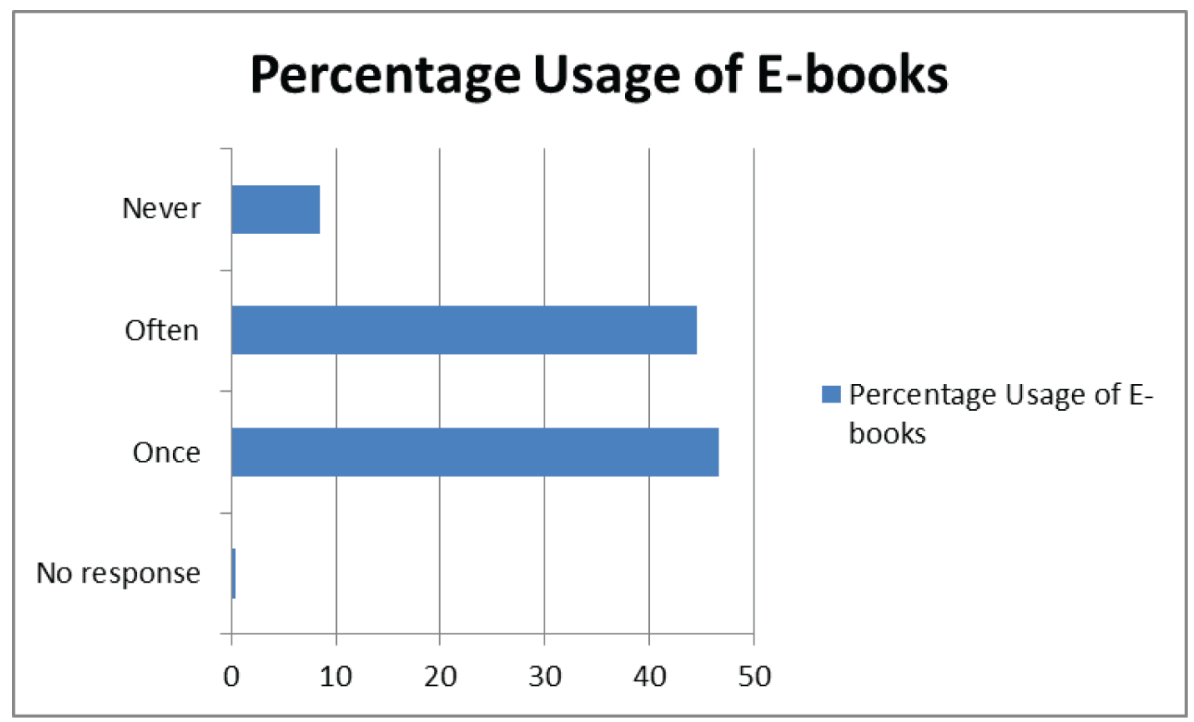

Table 4. e-book services used by respondents

\begin{tabular}{|l|l|l|}
\hline \multicolumn{1}{|c|}{ e-Book Services } & \multicolumn{1}{c|}{ Frequency } & \multicolumn{1}{c|}{ Percentage } \\
\hline E-brary eBooks & 139 & 49.1 \\
\hline Science Direct e-books & 97 & 34.3 \\
\hline Ebsco e-books & 22 & 7.8 \\
\hline
\end{tabular}

\subsection{Discovering e-Books}

The majority of respondents affirmed colleagues and lecturers were most popular methods of discovering and becoming aware of e-books, followed by library catalogue and library staff as shown in Figure 4. This negates the findings of ebrary (Jisc Collections, 2009) that library staff and library websites were most significant in finding out about e-books. This study contributes to literature on the importance of lecturers and colleagues in the promotion of e-books among students.

\subsection{Hypothesis Testing}

Table 5 shows that performance expectancy, effort expectancy and facilitating conditions were significant with coefficients less than 0.05 , and social influence was not significant. This implies that only performance expectancy, effort expectancy and facilitating conditions explain the intention to use e-books.

Regression analysis showed that Performance Expectancy predicts intention to use electronic books. This finding is consistent with research which states Performance Expectancy as the strongest predator of intention to use e-books. We therefore accept the hypothesis that performance expectancy influences the acceptance of e-books. 


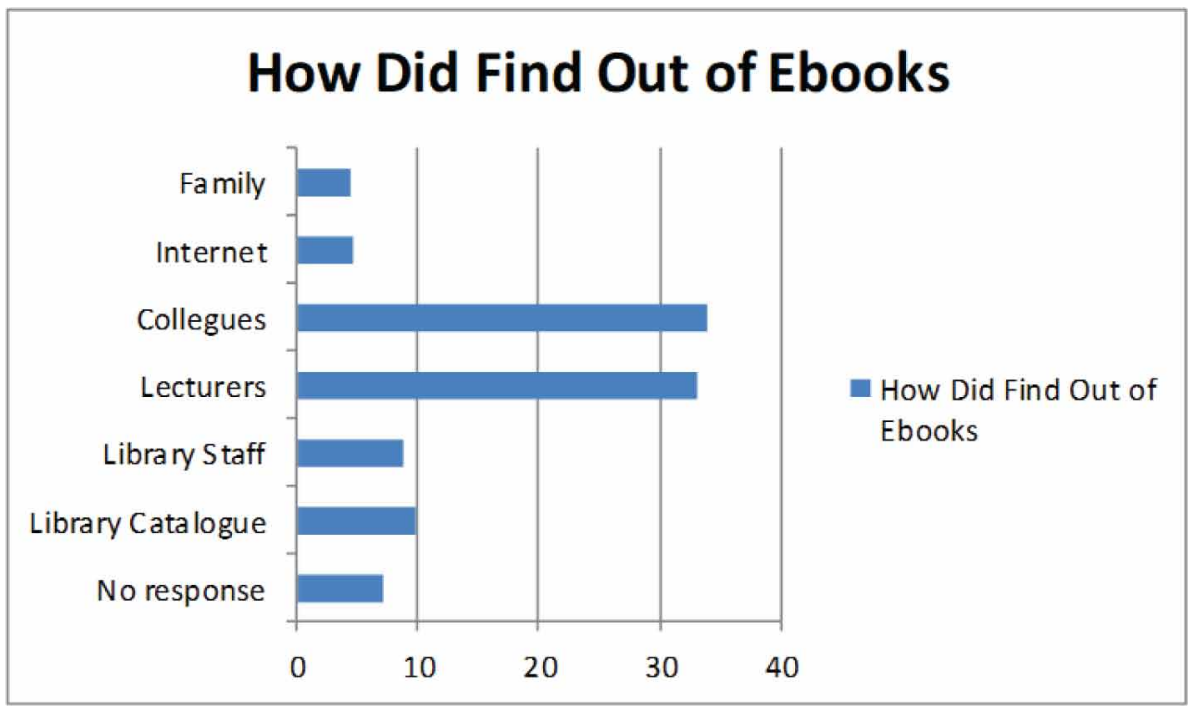

Table 5. Regression analysis of constructs

\begin{tabular}{|l|l|l|l|l|l|}
\hline \multirow{2}{*}{ Model } & \multicolumn{2}{|c|}{ Unstandardized Coefficients } & \multicolumn{2}{c|}{ Standardized Coefficient } & \multirow{2}{*}{ Significance } \\
\cline { 2 - 5 } & \multicolumn{1}{|c|}{ B } & Std. Error & \multicolumn{1}{c|}{ Beta } & \multicolumn{1}{c|}{ t } & \\
\hline Constant & 1.129 & 0.475 & & 2.376 & 0.018 \\
\hline Performance Expectancy & 0.239 & 0.056 & 0.220 & 4.277 & 0.000 \\
\hline Effort Expectancy & 0.239 & 0.053 & 0.278 & 0.484 & 0.000 \\
\hline Social Influence & 0.076 & 0.055 & 0.091 & 1.388 & 0.166 \\
\hline Facilitating Conditions & 0.183 & 0.053 & 0.217 & 3.432 & 0.001 \\
\hline
\end{tabular}

Effort expectancy construct also predicted intention to use electronic books with significance less than 0.01. This finding has implications for the design of electronic books databases. We accept the hypothesis that effort expectancy has significant influence on behavioural intention to use e-books.

Social Influence Construct did not significantly predict intention to use e-books. This implies that the opinion of others is not important in determining adoption of electronic books in Landmark University.

Facilitating Conditions construct is also proven to predict intention to use e-books (sig $=0.001$; $\mathrm{p}<0.005$ ) internet connectivity, speed of connectivity and lecturers support for e-books are important in determining intention to adopt electronic books. We accept the hypothesis that facilitating conditions significantly influences intention to adopt electronic books.

\subsection{Role of Gender on Behavioral Intention}

Gender did not show any moderating effect on intention to use e-books as male and female adopt e-books at similar rates which is corroborated by Madaku (2015). We therefore reject the hypothesis that gender has as significant relationship with intention to adopt e-books (see Table 6). 
Table 6. Gender moderating user acceptance

\begin{tabular}{|c|c|c|c|c|c|c|}
\hline \multicolumn{7}{|c|}{ Coefficients } \\
\hline & \multirow{2}{*}{ Model } & \multicolumn{2}{|c|}{ Unstandardized Coefficients } & \multirow{2}{*}{$\begin{array}{c}\begin{array}{c}\text { Standardized } \\
\text { Coefficients }\end{array} \\
\text { Beta }\end{array}$} & \multirow{2}{*}{$\mathbf{t}$} & \multirow{2}{*}{ Sig. } \\
\hline & & B & Std. Error & & & \\
\hline \multirow{2}{*}{1} & (Constant) & 6.614 & .443 & & 14.922 & .000 \\
\hline & Gender & .174 & .303 & .034 & .576 & .565 \\
\hline
\end{tabular}

\subsection{Discussion of Results}

The results of this study examined the factors that determine e-book adoption by undergraduate students in Nigeria. The results showed that $97.9 \%$ of undergraduate students are aware of electronic books but only $44.5 \%$ of students used it often, about $46.6 \%$ of students noted that e-books were used only once. These findings raise concern on the factors that limit the continued use of e-book technology which also negates findings by Wang and Bai, 2016) that awareness limits the adoption of electronic books. The study also showed that only $49.1 \%$ of undergraduate students were familiar with the E-brary e-book service provided by the university library which is well supported by Wang and Bai (2016) who revealed that usage of library provided e-book services is relatively low as majority of students downloaded e-books from search engines.

The study further investigated the factors that determine the adoption of electronic books by undergraduate students using the Unified theory of Acceptance and Use of Technology (UTAUT), results revealed Performance Expectancy, Effort Expectancy and Facilitating Conditions as major determinants for the adoption of electronic books by undergraduate students in Nigeria. The findings corroborate studies by Yoo and Roh (2017) and Joo and Choi (2015). This study confirms that when students perceive books as important with the ability to improve performance and create an enabling learning experience, it leads to higher rates of adoption. Similarly, effort expectancy is also considered as a significant factor in determining adoption as corroborated by (Verkijika, 2019; Terpend et al., 2014; Hung et al., 2012), which reveal that students consider e-book features difficult to navigate resulting in techno stress. Results also showed that facilitating conditions played a key role in the adoption of electronic books as the availability of reliable internet facilities, lecturer and institutional supports are paramount in determining the adoption of electronic books. This finding is corroborated by Nwagwu (2014) where the role of institutional support is considered paramount in driving e-book adoption. Results further showed that gender did not have significant moderating effect on e-book adoption. These findings have implications for library practitioners and university administrators in promoting the adoption of electronic books in Nigeria.

\section{CONCLUSION}

The study examined the adoption of electronic books by undergraduate students in Nigeria. Results from the study revealed the high awareness yet low usage of electronic books by undergraduate students in Nigeria. However, the study also evaluated the factors that determine the adoption of electronic books by students using the Unified Theory of acceptance and Use of technology (UTAUT) model. Results showed that Performance Expectancy, Effort Expectancy and Facilitating Conditions influenced the intention to adopt electronic books. It further revealed that gender did not play a moderating role on the adoption of electronic books. This study has practical implications on academic institutions and electronic book publishers in encouraging e-book use and improving e-book features to align with the needs of the millennials also providing reliable internet facilities and providing lecturer and institutional support in driving e-book adoption by undergraduate students. 


\section{REFERENCES}

Abutaleb, Y. (2012). Some universities require students to use e-textbooks. USA Today. Retrieved from http:// www.usatoday.com/money/markets/story/20120813/etextbooks/57039872/1

Aharony, N. (2014). The effect of personal and situational factors on LIS students' and professionals' intentions to use e-books. Library \& Information Science Research, 36(2), 106-113. doi:10.1016/j.lisr.2014.01.001

Ashcroft, L. (2011). Ebooks in libraries: An overview of the current situation. Library Management, 32(6/7), 398-407. doi:10.1108/01435121111158547

Asunka, S. (2013). The viability of e-textbooks in developing countries: Ghanaian university students' perceptions. Open Learning: The Journal of Open, Distance and e-Learning, 28(1), 36-50.

Gerhart, N., Peak, D. A., \& Prybutok, V. R. (2015). Searching for New Answers: The Application of TaskTechnology Fit to E-Textbook Usage. Decision Sciences Journal of Innovative Education, 13(1), 91-111. doi:10.1111/dsji.12056

Gu, X., Wu, B., \& Xu, X. (2015). Design, development, and learning in e-Textbooks: What we learned and where we are going. Journal of Computers in Education, 2(1), 25-41. doi:10.1007/s40692-014-0023-9

Huang, Y., Liang, T., Su, Y., \& Chen, N. (2012). Empowering personalized learning with an interactive eBook learning system for elementary school students. Educational Technology Research and Development, 60(4), 703-722. doi:10.1007/s11423-012-9237-6

Joo, S., \& Choi, N. (2015). Factors affecting undergraduates' selection of online library resources in academic tasks: Usefulness, ease-of-use, resource quality, and individual differences. Library Hi Tech, 33(2), $272-291$. doi:10.1108/LHT-01-2015-0008

Liu, Z., \& Huang, X. (2016). Reading on the move: A study of reading behavior of undergraduate smartphone users in China. Library \& Information Science Research, 38(3), 235-242. doi:10.1016/j.lisr.2016.08.007

Maduku, D. K. (2015). Factors of e-book use intentions: Perspective of students in a developing country. Perspectives on Global Development and Technology, 14(6), 597-618. doi:10.1163/15691497-12341364

Maduku, D. K. (2015a). An empirical investigation of students' behavioural intention to use e-books. Management Dynamics, 24(3), 1-19.

Maepa, M. E., \& Nkosi, D. (2013). The uptake of e-books on the African continent: challenges and prospects. In Proceedings of the African Library Summit. Academic Press. Retrieved from http://uir.unisa.ac.za/bitstream/ handle/10500/10128/maepa_e_als.pdf?sequence $=1$

Nwagwu, W. E., \& Okafor, J. L. (2014). Diffusion of e-books among postgraduate students of the University of Ibadan, Nigeria. Library Review, 63(1 \& 2), 86-109. doi:10.1108/LR-04-2013-0056

Potnis, D., Deosthali, K., Zhu, X., \& McCusker, R. (2018). Factors influencing undergraduate use of e-books: A mixed methods study. Library \& Information Science Research, 40(2), 106-117. doi:10.1016/j.lisr.2018.06.001

Raynard, M. (2017). Understanding academic e-books through the Diffusion of Innovations Theory as a basis for developing effective marketing and educational strategies. Journal of Academic Librarianship, 43(1), 82-86. doi:10.1016/j.acalib.2016.08.011

Shin, D.-H. (2011). Understanding e-book users: Uses and gratification expectancy model. New Media \& Society, 13(2), 260-278. doi:10.1177/1461444810372163

Terpend, R., Gattiker, T. F., \& Lowe, S. E. (2014). Electronic Textbooks: Antecedents of Students' Adoption and Learning Outcomes. Decision Sciences Journal of Innovative Education, 12(2), 149-173. doi:10.1111/dsji.12031

Venkatesh, V., Morris, M. G., Davis, G. B., \& Davis, F. D. (2003). User acceptance of information technology: Toward a unified view. Management Information Systems Quarterly, 27(3), 425-478. doi:10.2307/30036540

Verkijika, S. F. (2019). Digital textbooks are useful but not everyone wants them: The role of techno stress.

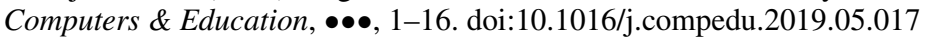


Wang, S., \& Bai, X. (2016). University students' awareness, usage and attitude towards ebooks: Experience from China. Journal of Academic Librarianship, 42(3), 247-258. doi:10.1016/j.acalib.2016.01.001

Yoo, D. K., \& Roh, J. J. (2016). Use and uptake of E-books in the lens of unified theory of acceptance and use of technology. Retrieved from http://aisel.aisnet.org/cgi/viewcontent.cgi?article=1116\&context=pacis 